\title{
Noun Class System of Kusaal ${ }^{1}$
}

\author{
Hasiyatu Abubakari \\ University of Ghana, Legon
}

\begin{abstract}
It is common knowledge that noun classes in Mabia (Gur) languages are primarily characterized by stems and affixes. Common to all studies on nominal classification in Kusaal is the observation that nouns that exhibit common morphological properties also share identical semantic features. Though this is true to some extent, the generalization breeds a lot of leakages because classifications based on semantic field alone is unable to explain the inclusion of nouns that share identical morphological and phonological features but different semantic features. Thus, this problem questions the assumption that noun classification in Kusaal is dependent on common semantic properties or coherence shared by all nouns in a group. The semantic classification of nouns, in this study, is composed based on the assumption that speakers of Kusaal put together nouns that are connected by identical semantic features and others that are linked by pragmatic associations into networks that define concepts and aspects of their survival as human beings. It is further observed that nouns within such groups also go through identical phonological rules or constraints. Nouns in this paper are classified based on their morphological features which are closely knit to their semantic networks as well as phonological constraints. The framework of Lexical-Phonology is employed in analyzing the morphophonological components of the nominal classification system of the language.
\end{abstract}

Keywords: Nominal classes, morphology, phonology, semantics, Kusaal,

\section{Introduction}

This paper explores the nominal class system of Kusaal and argues that the classification system involves a complex interaction of semantics, morphology and phonology. Six nominal classes have been identified which reveal a correspondence between semantic affiliations and morphological patterns. These patterns further reveal systematic phonological processes governing each identified nominal class. It is hypothesized that in Kusaal nominal classification, morphology interacts with semantics and phonology in interesting ways and this paper will show in detail how that happens. The aim of this study is to offer a formal analysis of the concept using the theoretical framework of Lexical-Phonology (Kiparsky 1985; Mohanan 1986; Bodomo and Marfo 2006).

Kusaal is a Mabia (Gur) language, (see Bodomo 2020), spoken in the Upper East Region of Ghana. It is an SVO language where any form of word order alternation has direct impact on the discourse interpretation of the 'moved' constituent(s). There are two dialects of Kusaal: Agolle (spoken in Bawku Municipal and its adjoining villages) and Atoende (spoken in the Bawku West District thus, Zebilla and surrounding villages as well as in Burkina Faso). The data used in this paper was gathered on several trips of field work to Bawku (Municipal) and its surrounding villages. The author's intuition as a native speaker of both dialects also played a role. There is not much

\footnotetext{
${ }^{1}$ Sponsorship: Aspects of this paper is taken from a major project titled: The Grammar of the Kusaal Language of Ghana with support from the African Humanities Program (2021) of the American Council of Learned Society.
} 
difference in the system of noun classification between the two dialects. However, data used in this work is more representative of the Agolle dialect.

This work is organized into five sections. Section two gives an overview of previous studies on the nominal classification in Kusaal. The section further provides some background information on nouns in Kusaal focusing on aspects that will be relevant for discussions in this paper. The third section considers the morphophonology of the nominal system in Kusaal. In this section, I explore the interface between morphology and phonology in the derivation of nouns in all the classes. This is done using the framework of Lexical-Phonology. The fourth section discusses the semantic network that exists between nouns of the various classes. The semantic classification of nouns corresponds with regular morphological patterns that characterize each identified class. Additionally, it will be observed that nouns in specific classes mostly exhibit identical phonological patterns. Thus, similar phonological processes are tied to nouns in specific groups in the formation of both the singular and the plural forms. This leads to the assertion that morphology and phonology play integral roles in the derivation of both the singular and plural forms of nouns in all classes. The fifth section is the conclusion.

\section{Previous accounts of nominal classification in Kusaal}

Earlier studies have shown that about two thirds of the languages in Africa have some kind of noun classification mainly based on affixes (Welmers 1973:159; Heine 1982; Naden 1989; Katamba 2003:10; Bodomo and Marfo 2006; Miehe et al 2007, 2012). The classification of nominals in Mabia (Gur) languages are usually based on stems and affixes which are predominantly suffixes (Rapp 1966; Dakubu 1996; Bodomo 1997; Olawsky 1997; 1999; Nsoh 2002; Miehe et al 2007, 2012; Abubakari 2011, 2018; Bodomo and Abubakari 2017; Niggli 2014; Eddyshaw 2016; Musah 2018). The trend further reveals some correlation with semantic classification where most of the nouns in an identified group form a semantic network; they share similar semantic features and also include others that are linked by pragmatic associations (Breedveld 1995; Contini-Monrova 1994; Lakoff 1987). Contini-Morava (1994) opines that the semantic approach to nominal classification has been one major area of consideration adopted by linguists and anthropologists in studies of the phenomena. This is because the classification of nouns into groups reveals a system of cognitive or cultural classification which underlies the system of linguistic classification. In addition, noun classification is an intrinsic component of grammar and lexicon and lies between inflection and derivation; it also hints at the way people use language to reflect their culture, perception, environment, religion among other things. Through language, one is able to understand the worldview of a particular group of people. The vocabulary of a language, including nominal elements, plays an important role as a window into the universe of knowledge of its speakers and their perception of the world around them (Agyekum 2006; Sapir 1949; Mphande 2006:105-106). The semantic classification of nouns into groups by the Kusasis, reflect their worldview; perceptions, belief system and their culture and tradition (Abubakari 2020).

A considerable amount of effort has been made in the literature on the classification of the nominal system of Kusaal (Abubakari 2011, 2018; Niggli 2014; Eddyshaw 2016; and Musah 2018). Though there is general consensus in the claim that the singular and plural forms of nouns in the language are composed of stems and suffixes, different authors arrive at different numbers of available classes. This could partly be due to the different approaches to nominal classification adopted by these authors. What appear close are the works of Eddyshaw (2016), with the following class groupings: $\left\{1-{ }^{a} / b^{a}\right.$, and $\left.b^{a} / n a m, 2-g^{a} / s^{\varepsilon}, 3-g^{\jmath} / d^{e}, 4-r^{\varepsilon} a^{a+}, 5-f^{\rho /+}, 6-b^{\supset}, 7-m\right\}$, and Abubakari 
(2018), with the following class groupings $\{1 \mathrm{a}-a, 2 \mathrm{a}-b a, 1 \mathrm{~b}-\mathrm{V},-b a, 2 \mathrm{~b}-n a m a, 3-g \mathrm{~V}, 4-s \downarrow \varepsilon, 5-f \supset$, $6-g i, d i, 7-g \mathrm{~V}, 8-d \varepsilon, 9-r \mathrm{~V}, 10-a a, 11-m\}$. The former identifies seven classes putting both singular and plural forms of a particular group together whilst the later identifies 11 groups counting singular and plural forms as separate classes. Both studies also discuss the morphology, phonology as well as semantics (noun meanings) of the nominal system of Kusaal. This study merges the singular and plural forms of nouns into one class reducing the 11 classes in Abubakari (2018) to six classes. Thus, nouns are grouped based on their singular and plural suffix morphemes.

Musah (2018:98-111), on his part, identifies the following classes of nouns: $\{1 / 2-\mathrm{V},-\mathrm{d} /-$ b, -Ø/nam, 3/4 -vy/-Ni, 5/6 -r/-a, 12/13 -g/-s, 15/21 -g/-d, 19/4 -fl-I, 20/13 -bil/-bibis, 14 -b, 22/23 $m\}$. Singular classes are paired with corresponding plural classes. Thus, class 1 is the singular and class 2 the plural of class one. The classification is largely based on morphosemantic features. However, no mention is made in Musah (2018) of the long and short forms of lexical items in Kusaal. Long and short forms of lexical items (discussed in subsection 2.1) are very common in the language (Abubakari 2017, 2018; Niggli 2014; and Eddyshaw 2016). Whereas the long forms are used in questions and negation the short forms are used elsewhere.

Niggli (2014:98-117) also looks at the noun class system of the Kusaal spoken in Burkina Faso which, although an Atoende dialect, exhibits some differences with the variety spoken in Ghana. Niggli's work focused mainly on the morphological patterns in the noun class system of the language. In all, 14 classes are identified represented as follows $\{1$. (sg) $-a, 2$. (pl) $-b a /-p, 3$. (sg) $\varnothing /-b a /-m a /-p, 4 .(\mathrm{pl})$-nama/nam, 5. (sg) -ga/-k(a)/p(a)/-wa/-ya, 6. (pl) -sE, 7. (sg) -gO/-kO/-pO/ne, 8. (pl) -rt/-tt/-t/Et/-Ot, 9. (sg) -rE/-lE/-ne/-dE/-bE/-t, 10. (pl) -a/-ya, 11. (sg) -fO, 12. (pl) - gi/-i/-Ø, 13. $-b O, 14 . \mathrm{m} / \mathrm{um} / \mathrm{-lim} / \mathrm{sim}$ \}. This could partly be explained to be due to the fact that what has been merged as classes 1 and 2, in Abubakari (2018) and in this paper, are broken down into four classes in (Niggli 2014). Dialectal differences could potentially have an impact though this claim needs further investigation.

In short, noun classes in Kusaal have generally been defined based on morphology, phonology and semantics. What is of major concern has to do with the semantic approaches to nominal classification in the language. Common to all studies is the assumption that nouns that exhibit common morphological properties also share identical semantic features. This is true to some extent since some of the noun classes can be described as forming semantic fields. However, the generalization breeds a lot of leakages because classifications based on semantic field alone are unable to explain the inclusion of some nouns that share identical morphological and phonological features but different semantic features. Thus, this problem questions the assumption that noun classification in Kusaal is dependent on common semantic properties or coherence shared by all nouns in a group. It asks for a more comprehensive approach which requires a more heterogeneous list (Contini-Monrova 1994:4). Though the suggestion for the inclusion of a heterogeneous list has been challenged mostly from the point of view of Cognitive Grammar (cf. Lakoff 1987; Langacker 1987, 1990; Rudzka-Ostyn 1988), the argument has been that membership in a given linguistic category (for instance a noun class) may be based on multiple criteria, which include: family resemblances, metaphor, and metonymy, and that linguistic categories may exhibit an internal structure in which some members of the category are more central, or prototypical, and others are more peripheral (Contini-Monrova 1994). Accordingly, this approach allows for the creation of more intricate associative links, both semantic and phonological that connect a noun to a particular class, and also look at semantic domains that intersect with more than a single class, to show patterns of relationship between the classes (Contini-Monrova 1994). The proposal is that the semantic classification of nominals in Kusaal be carried out using the concept of semantic network. Nouns 
may be related by association in which instance they do not necessarily share a similar semantic field but may be found in a pragmatic relation to one another based on their occurrence in identical contexts. The membership of a particular class of nouns can be described as a composition of a semantic network of association (see Breedveld 1995:65). Going by this proposal, just a handful of nominal classes in Kusaal can be described as forming a semantic field whilst majority can be said to be composed by a semantic network of association.

The current study, part of which is taken from Abubakari (2018), is aimed at giving a detailed description and analysis of the phenomenon as it occurs in the language. Whereas no formal account of the system is given in Abubakari (2018) as well as other previous studies of nominal classifications in Kusaal, this paper aims to fill that gap. The formalization will be done using the framework of Lexical-Phonology. This analysis shows in details both the morphological and phonological processes that underlie the formation of nouns in all identified classes. More importantly, the semantic approach adopted in Abubakari (2018) is based on semantic features which shows some leakages hence the need to revisit the analysis for a more comprehensive approach.

2.1. Background on Nouns in Kusaal. Nouns in Kusaal come in two forms: "short forms" and "long forms" (Abubakari 2017, 2018; Niggli 2014). The short forms are derived from the long counterparts by dropping the final vowel of the suffix when this will not result in a word-final consonant cluster. Example (1) is an illustration of nouns showing both short and long counterparts.

(1)

\begin{tabular}{|c|c|c|c|}
\hline Nominal & Singular & & Plural \\
\hline & $\begin{array}{l}\text { Long } \\
\text { sídá }\end{array}$ & $\begin{array}{l}\text { Short } \\
\text { sid }\end{array}$ & $\begin{array}{l}\text { Long } \\
\text { sídibá }\end{array}$ \\
\hline Room & d’่̀̀gù & d’̀̀̀g & $d \grave{\jmath} d \varepsilon$ \\
\hline 'child' & biígì/bíigá & biíg & biísì/biísá \\
\hline
\end{tabular}

The short and long forms are used in different contexts. The long forms appear in questions and negation while the short forms appear elsewhere, for instance, they are used in declarative sentences, as demonstrated below.

(2) Short forms in declarative constructions

$\begin{array}{lll}\text { Àsíbí àné m } & \text { búg /* búigá } \\ \text { Asibi is } & \text { 1Sg.Poss } & \text { child } \\ \text { 'Asibi is my child.' } & \end{array}$

(3) The long forms in questions and negation

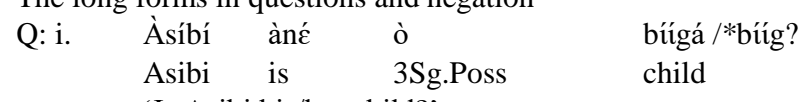

'Is Asibi his/her child?'

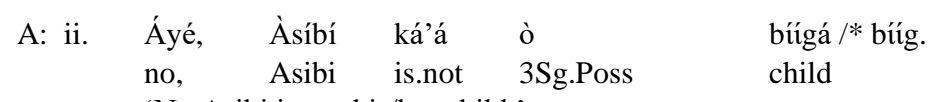

'No Asibi is not his/her child.'

A: iii. 'éćn, Àsíbí àné ò bíg/ *búígá.

yes, Asibi is 3Sg.Poss child

"Yes, Asibi is his/her child.' 
Nouns that have both long and derived forms will be identified, and both forms will be listed in the data used in this paper. Any time a noun is modified by a qualitative adjective the stem of the noun form combines with the adjective. If the noun is plural, this is marked on the adjective.

(4)

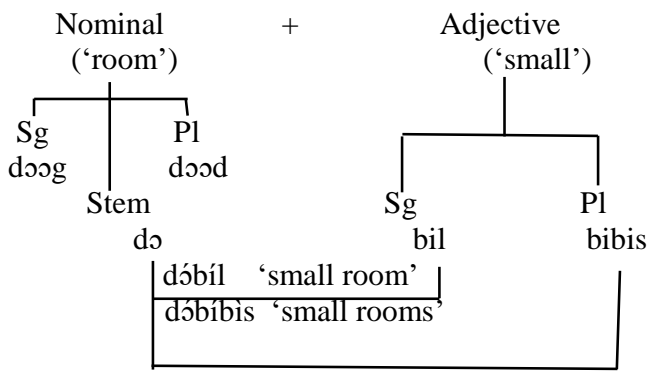

In this work, I identify the stems of the nouns by taking the forms that combine with the adjective (see Abubakari 2018, Anttila and Bodomo 2009).

2.2. Background on the Morphosemantics of Nominal Classes in Kusaal. A study of the nominal morphology of Kusaal reveals a pattern where singular and plural nouns are distinguished mainly by suffixes. Pronouns do not show any form of agreement in whatever form or use they may be put to. Class concord, though present in a closely related language, Gurene (Nsoh 2002), is not a characteristic of nominal classification in Kusaal. Singular and plural nouns of the same word take different suffix morphemes. As previously indicated, all suffixes that have a CV form can drop the final vowel. Final vowels that can be dropped are put in brackets. In this study, the classification of nouns is carried out based on the following suffix morphemes: (1a) -V/-b(a), (1b) -a/-nam(a), (1c) $-b(a) /-n a m(a),(2)-g(\mathrm{~V}) /-s(\mathrm{~V}),(3)-g(\mathrm{~V}) /-d(\varepsilon),(4)-f(0) /-g(i),(5)-r(\varepsilon) /-a$, and (6) $-m$.

A brief outline of the morphemes that inform each categorization is presented as below. The group numbered (1a) is represented as $-V /-b a$ where $\mathrm{V}$ could either be $-a$ or $-u$, e.g., pú 'áá 'woman/wife', pú 'ábá 'women/wives', pitv 'sibling', pitíba 'siblings', etc. For (1b), the suffix - $a$ is used for singular and -nam(a) is used for the plural counterpart. Examples are màa 'mother', mànàmà 'mothers', bà'a 'father', bà 'ànàmà 'fathers', etc. Nouns in (1c) take the suffix -ba for the singular and -nam(a) for the plural, e.g., yáábá 'ancestor', yaánamá 'ancestors', náábá 'chief' ná 'ánàmá 'chiefs', etc. The nouns in (1a) -V/-b(a), (1b) -a/-nam(a), and (1c) b(a)/-nam(a) are grouped as a single class. The decision to group all these in one class is based on the observation that whilst (1a) and (1b) share a common singular suffix, (1b) and (1c) share a common plural suffix morpheme. All three, more importantly, share a common semantic network feature [+ human, +kin relationship]; a revelation that nominal classification in the language goes beyond morphology to include semantic association of members, as will be discussed extensively in the subsequent sections. The distinction between (1a), (1b) and (1c) is that the nouns in (1b) refer to people who command a higher degree of respect in society compared to those in (1a). Nouns in (1c) also refer to people who are revered higher than those in (1b). This analogy is illustrated below using an item each from the categories in (1a), (1b) and (1c) where the item preceding the symbol, ' $<<$ ', commands a lesser degree of respect to the item following it.

pú 'áá 'woman/wife', pú 'ábá 'women/wives' << màa 'mother', mànàmà 'mothers' $<<$ yáábá 'grandparent/ancestor' yaánamá 'grandparents/ancestors. 
Class one is the human class; by default, it also has items such as borrowed words with varied semantic compositions but related morphological patterns. The data for this class of nominals show that more words take the suffix -nam(a) compared to the suffix - $b a$ when the latter is used either as a singular or a plural suffix. Another class of nominals in this study is made of nouns that take the suffixes $-g(V)$ and $-s(\boldsymbol{\nu} / \dot{\varepsilon})$ for the singular and plural respectively. The $\mathrm{V}$ for the singular could be any of the vowels $\{a, i, 1, v, \supset, \varepsilon\}$, depending on the ATR status of the vowel in the stem. Examples include: wábígá 'lame person' wábísi/ć 'lame persons' gika 'dumb person' gígísi/ć 'blind persons', and lólv́gó 'ox', lólísilé 'oxen'. There is also a class which is composed of nouns that take the suffix $-g(v / \rho)$ and $-d(\varepsilon)$ for the singular and plural respectively. Some nouns in this category

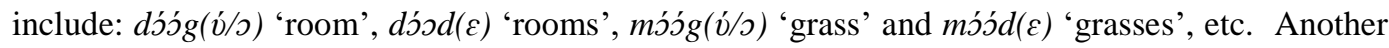
observed class is a group of nouns that take the suffix $-f$ for the singular and - $g i$ for the plural. Examples are ná'áfj̀ 'cow', níigì 'cattle', and wááf’ 'snake', wílgì 'snakes'. Additionally, there are nouns that take the suffix $-r(\varepsilon / i)$ for singular and - $a$ for the plural, e.g., túbirì/e 'ear', túbàa 'ears', and bin'ísirík 'breast', bin'ísáa 'breasts', etc. Finally, the class of non-count nouns take the suffix $m$ as in: kú'òm 'water', ziím 'blood', and bin'ísím 'milk', among others.

With this background, the subsequent discussions look at the various classifications of nouns in Kusaal using their morphology, phonology and semantics (morphophonology and morphosemantics).

\section{The interface between morphology and phonology in Kusaal nominal classifications}

This section provides a morphophonological analysis of the six classes of nouns identified in Kusaal by employing the theoretical machinery of Lexical Phonology (LP). These classes are, here, identified by their morphological suffixes which will soon be discussed in detail: Class 1- $-V /-b(V)$, $b(V) / n a m(a)$, Class 2- $-g(V),-s(V)$, Class 3- $-g(V) /-d(\varepsilon)$, Class 4- $-f(V) / d i$, -gi, Class 5- $-r V /-a(a)$ and Class 6- $/-m /$. The section describes the morphological (word formation processes) operations and the phonological rules and constraints that derive the various singular and plural nouns in all the identified nominal classes. LP is a framework that is used to analyze the interface between phonology, morphology as well as syntax. It is argued that a subset of phonological rules applies in the lexicon together with some morphological operations. Another subset of these rules applies postlexically. The output of each level of phonological operations may undergo a morphological operation, and the process can keep on repeating itself until the desired lexical representation (output) is realized. From the diagram below, phonological rules apply to underlying morphological units that are supplied by the lexicon. The phonological rules are divided into two. The rules that apply within word boundaries (and can be cyclical) are referred to as lexical and those that are interboundary sensitive (not cyclical) are called post-lexical (Kiparsky 1985; Mohanan 1986; Bodomo and Marfo 2006). 
Table 1

Level 1:

LP proposes that in every word formation process, the morphological component supplies the various stems, affixes as well as word forms of the language on which the necessary lexical rules of the language apply to modify and produce the phonetic form. On this basis and following Bodomo and Marfo (2006) and Bodomo (1997), it is stipulated that any natural language lexicon has an inventory of stems, affixes as well as word forms whose meanings are not predictable from their constituent parts. Word formation is therefore composed of rules (WFRs) which describe the potential words of the language. The rules below are examples of what applies to Kusaal.

Table 2. Morphological Rules

\begin{tabular}{|c|l|l|l|}
\hline $\begin{array}{l}\text { Word Formation Rule } \\
\text { (WFR) }\end{array}$ & & $\mathrm{N}$ \\
\hline i. & NounStem-Sfx & $:$ bi-gi 'child' & $\rightarrow \mathrm{N}$ \\
ii. & Verbstem-Sfx & $:$ kuo-b 'farming' & $\rightarrow \mathrm{N}$ \\
iii. & Nounstem-Adjectivesten & :bi-bil 'little baby' & $\rightarrow \mathrm{N}$ \\
iv. & Nounstem-Nounstem & :bi-buruy 'baby boy' & $\rightarrow \mathrm{N}$ \\
\hline
\end{tabular}

The word formation processes in table (2) show the creation of new words in the language. The presence of the morpheme $b i$ and the affix $g(i)$ predicts WFRi; which means $b i g(i)$ is a potential word in Kusaal. Again, following WFRii; it is possible to predict kuob in the lexicon of the language as constituting a stem of a verb kuo and an affix $-b$. The examples so far point to only one level representation since there is only one word-formation rule. It is therefore argued that Kusaal has only one cycle and one level.

This is only a morphological explanation. It is inadequate in capturing the phonetic realizations of lexical items. We need phonological explanations to make full sense of our observations of the data presented. As argued by Bodomo and Marfo (2006), the stem and affixes are solely underlying constituents which are underspecified for certain phonological features such as ATR, Vowel lengthening, and Vowel insertion.

With reference to the model sketch of LP in table (1), the linkage: Morphology $\leftrightarrow$ Phonology represents the necessary interaction needed to realize the true lexical representation. Phonologically, let us consider a vowel harmony (VH) rule, a vowel lengthening rule (VL) and an additional final vowel deletion rule modeled from Bodomo and Marfo (2006:222-3):

\section{Table 3. Major Phonological Rules}

\footnotetext{
i. $\quad \mathrm{VH}: \mathrm{V}[\alpha \mathrm{ATR}] \rightarrow / \mathrm{V}[\alpha \mathrm{ATR}]$

ii. $\quad \mathrm{VL}: \mathrm{V} \rightarrow \mathrm{VV} / \mathrm{C}-\mathrm{gI}$
} 
iii. FVD: $\mathrm{FV} \rightarrow \varnothing / \mathrm{C}-\mathrm{g} \varnothing$

VH simply implies that the affix vowels take the ATR specifications of the vowel in the stem. The VL rule lengthens any stem vowel that takes the suffix $-g I$. A similar observation is discussed by Anttila and Bodomo (2009) for Dagaare. They intimate that at least some cases of vowel lengthening are conditioned by foot structure. Further work needs to be done for Kusaal to find out if same can be said to apply. The FVD rule deletes the final vowel of the affix. I demonstrate how these rules occurs in Kusaal at level 1 of the LP model using the lexicon bi- (stem) and $-g I$ (suffix).

Table 4.

\begin{tabular}{|l|l|}
\hline WFR & Kusaal \\
\hline Underlying representation & $:[[b i-[-g I]]$ \\
Step 1 WFR (NounStem-Sfx) applies & $:$ bi-gI \\
Step 2 VH $\left(\mathrm{V}[\alpha \mathrm{ATR}] \rightarrow / \mathrm{V}[\alpha \mathrm{ATR}] \_\right.$) applies & $:$bi-gi \\
Step 3 VL $(\mathrm{V} \rightarrow \mathrm{VV} / \mathrm{C}-\mathrm{gI})$ applies & $: b i i-g i \quad$ 'child' \\
Step 4 FVD $(\mathrm{FV} \rightarrow \emptyset / \mathrm{C}-\mathrm{g})$ applies & $: b i i-g \quad$ 'child' \\
\hline
\end{tabular}

In this illustration, the morphological rules combine the stem and affix. But the affix in the stem remains unspecified for ATR. The phonological rule ensures that the harmony principle changes the affix to the correct phonetic form: $b i$-gi. VL further applies to realize the correct surface realization of biigi. To further realize the short form of the lexeme, FVD rule applies to produce biig.

3.1. LP analysis of the nominal classes in Kusaal. This section explains the morphological and phonological processes that account for the various noun classes identified in Kusaal. There are major generalizations that run through all the noun classes in the language. These include: WFRi (morphological), and VH (Phonological). Thus, this shows that all the nouns are composed of Stemaffix/affix-stem combinations and contain [+ATR] or [-ATR] vowels. The various rules for each group or category follow a specific order to the realization of the final output. Morphological rules must precede phonological rules. Additionally, the various phonological rules, as in Table (3), for instance, must also apply following the specific order, (i) to (iii). This is because most of the rules feed into the following ones. WFRi is always highest or first, and applies to all nouns, whilst the Final Vowel Deletion (Apocope) rule must always be the lowest or the last to apply. Apocope is used to derive the short forms of the noun. Any changes made to the order of the rule applications in each category will potentially make it difficult for other rules to apply. For instance, it is impractical to have a vowel harmony rule applying when WFRi has not taken place. The symbol >> is used to mark ranking of the rules such that WFRi $\gg$ VH $\gg$ FVD means that WFRi is first followed by VH followed by FVD.

Class 1: -V/-b(V), b(V)/nam (a)

This class goes beyond having $\mathrm{V} / b \mathrm{~V}$ suffix as common to most Mabia (Gur) languages where $\mathrm{V}$ represents a vowel, for the singular and plural respectively. Other identified suffixes are: $b(\mathrm{~V}) / \operatorname{nam}(a)$ for singular and plural respectively as well as $-a / \operatorname{nam}(a)$ also for singular and plural respectively. The morphological rule that applies here is WFRi and the phonological processes that are commonly observed in the class are: final vowel deletion (FVD/Apocope) in all the derived/short forms of nouns, vowel insertion (VI) to break any consonant cluster and vowel harmony (VH). 
Table 5. Class 1: -V/-b(V), b(V)/nam (a)

\begin{tabular}{|c|c|c|c|c|c|}
\hline Stem & WFRi & $>>$ & $\gg \mathrm{VH}$ & $\gg$ FVD & Gloss \\
\hline nid & :nid-A & - & $>$ nida & $>>$ nid & 'person' \\
\hline nid & :nid-A & - & $>>$ nida & - & 'person' \\
\hline nid & :nid-bA & $>>$ nid-I-bA & $\gg$ nidiba & $\gg$ nidib & 'persons' \\
\hline nid & :nid-bA & $>$ nid-I-bA & $\gg$ nidiba & - & 'persons' \\
\hline yaa & :yaa-bA & - & $\gg$ yaaba & > yaab & 'ancestor' \\
\hline yaa & :yaa-bA & - & >> yaaba & - & 'ancestor' \\
\hline yаa & :yaa-nAmA & $\mathrm{A}$ & > yaanama & > yaanam & 'ancestors' \\
\hline yaa & :yaa-nAmA & $\mathrm{A}$ & $>$ yaanama & - & 'ancestors' \\
\hline
\end{tabular}

Class 2: -g(V), -s(V)

This offers a regular pattern in the nominal system of the language. Unlike class 1 which has two suffixes each for the singular and plural, class 2 has just one suffix each for the singular and plural. The singular forms of class 2 take the suffix $-g(\mathrm{~V})$ whilst the plural forms take the suffix $-s(\mathrm{~V})$. The rules that apply here are WFRi, vowel lengthening (VL), vowel harmony, and final vowel deletion (FVD).

Table 6. Class 2: $-g(\mathrm{~V}),-s(\mathrm{~V})$

\begin{tabular}{|c|c|c|c|c|c|c|}
\hline Stem & WFRi & VL & $\gg$ & $\mathrm{VH}$ & $\gg$ FVD & Gloss \\
\hline$\overline{b i}$ & $: b i-g I$ & $>$ biigI & $>>$ & biigi & $>$ biig & 'child' \\
\hline$b i$ & $: b i-g I$ & $>$ biigI & $>$ & biigi & - & 'child' \\
\hline$b i$ & $\therefore b i-s I$ & $>$ biisI & $>$ & biisi & $\gg$ biis & 'children' \\
\hline$b i$ & :bi-s-I & $\gg$ biisI & $\gg$ & biisi & - & \\
\hline
\end{tabular}

\section{Classes 3:}

This group also has a regular pattern in the system. Nouns in class 3 take the suffixes $-g(\mathrm{~V})$ for singular and $-d(\varepsilon)$ for plural respectively. There are four rules that apply in this category: WFRi, vowel lengthening (VL), vowel harmony (VH) and final vowel deletion (FVD).

Table 7. Class 3: $-g(\mathrm{~V}) /-d(\varepsilon)$

\begin{tabular}{|c|c|c|c|c|c|}
\hline Stem & WFRi & $\gg \quad$ VL & $\gg \mathrm{VH}$ & $>$ FVD & Gloss \\
\hline$F u$ & $\therefore f u-g U$ & > fuugU & $>>$ fuugu & $>$ fuug & 'dress' \\
\hline$f u$ & $\therefore f u-g U$ & $>\quad f u u g U$ & $>>$ fuugu & - & \\
\hline$f u$ & $: f u-d E$ & $>$ fuudE & $>$ fuude & $\gg$ fund & 'dresses' \\
\hline$f u$ & $: f u-d E$ & $>\quad$ fuudE & $>>$ fuude & 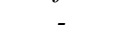 & \\
\hline
\end{tabular}

Class 4:

Nouns in this group are also regular and constitute the set with the least number of memberships. The nouns take the singular suffix $-f 3$ and the plural suffix $-g i$ or $-d i$. The following are the phonological rules that apply in this category after the morphological rule (WRi): vowel harmony (VH) and final vowel deletion (FVD). There is also some kind of stem suppletion as well. The change of the stem form from, for example naa to nil and waa to wll etc., without any change in meaning, results in suppletive allomorphy. 
Table 8. Class 4: $-f(\mathrm{~V}) / d i$, -gi

\begin{tabular}{|c|c|c|c|c|}
\hline Stem & WFRi & $\gg \mathrm{VH}$ & $\gg$ FVD & Gloss \\
\hline$n a ' a$ & $\therefore n a^{\prime} a-f O$ & $>>n a$ afo & $>n a^{\prime} a f$ & 'cow' \\
\hline$n a^{\prime} a$ & $\therefore n a^{\prime} a-f O$ & $>>n a^{\prime}$ afo & - & \\
\hline$n a^{\prime} a$ & $: n a^{\prime} a-g I$ & $>>n a^{\prime} a g l$ & $>$ nilg & 'cattle' \\
\hline$n a^{\prime} a$ & $\therefore n a^{\prime} a-g I$ & $>>n a^{\prime} a-g l$ & $>$ nilgl & 'snake' \\
\hline waa & $\therefore w a a-f O$ & $>>$ waafs & $\rightarrow$ waaf & 'snakes' \\
\hline waa & $\therefore w a a-f O$ & $>>$ waafs & - & \\
\hline waa & $\therefore w a a-g I$ & $>>$ waagl & wllg & \\
\hline waa & $: w a a-g I$ & $>>$ waagl & $>>$ & \\
\hline
\end{tabular}

\section{Class 5: $-r \mathrm{~V} /-a(\mathrm{a})$}

The singular form in class 5 takes the suffix $-r(\varepsilon)$ and the plural form takes the suffix $-a(a)$. However, the singular suffix is realized as $-\operatorname{ir}(i / \varepsilon)$ in a $\mathrm{C}-\mathrm{C}$ environment. The plural suffix $-a$ is also realized as $-y a$ in a $\mathrm{V}-\mathrm{V}$ environment. Both vowel and consonant insertions are meant to break undesirable clusters of consonants in the former and as a form of hiatus resolution in the latter where the glide (y) is used to break the heterosyllabic sequence of vowels. The rules that apply here are: WFRi, consonant/vowel insertion (CI/VI), vowel harmony (VH), and final vowel deletion (FVD).

Table 9. Class 5: -rV/-a(a)

\begin{tabular}{|c|c|c|c|c|c|}
\hline Stem & WFRi & $\mathrm{CI} / \mathrm{VI}$ & $\gg \mathrm{VH}$ & FVD & Gloss \\
\hline zuo & : zuo-rI & - & $>$ zuorl & zuor & 'mountain' \\
\hline zuo & $\therefore z u o-A A$ & $>>z u o-y-A A$ & $>$ zиоуаа & zиoуа & 'mountains' \\
\hline$z$ zuo & $: z u o-A A$ & $>>z u o-y-A A$ & >> zиоуаа & & \\
\hline$t v b$ & $\therefore t v b-r I$ & $>t v b-I-r I$ & $>>$ tvbirl & $\gg$ tvbur & ‘ear’ \\
\hline$t v b$ & $\therefore t v b-r I$ & $>t v b-I-r I$ & $>>$ tvbirl & - & \\
\hline$t v b$ & $: t v b-A A$ & - & $>$ tvbaa & tvba & 'ears' \\
\hline$t v b$ & $: t v b-A A$ & - & $>$ tvbaa & - & \\
\hline
\end{tabular}

\section{Class 6: - $m$}

Class 6, which has the suffix $-m$, is the only class that does not have singular-plural pairs. The rules that apply here are: WFRi and vowel lengthening (VL).

Table 10. Class 6: $-m$

\begin{tabular}{|l|l|l|}
\hline Stem & WFRi $>$ VL & Gloss \\
\hline $\begin{array}{l}k u o \\
z i\end{array}$ & $: k u o-m$ & 'water' \\
& $: z i-m$ & 'blood' \\
\hline
\end{tabular}

This section sought to analyse the morphological and phonological processes that take place in the formation and subsequent classification of nominals into various classes in Kusaal. It is observed that nouns in the various classes undergo similar morphological and phonological conditions in deriving their singular and plural forms. The next section looks at the morphosemantics and morphophonology of nominals in the various classes. 


\section{The morphosemantics and morphophonology of nominal classifications in Kusaal}

Nominal classes in Kusaal exhibit different degrees of internal semantic coherence. For instance, class 1 comprises mostly of human while class 5 comprises mostly of animals. Members of other classes are associated by strong semantic networks. The semantic network approach adopted for the classification of nominals follows similar studies conducted in Swahili (Contini-Monrava 1994) and Fulfulde (Breedveld 1995). Nouns that belong to a semantic network also have identical suffixes and undergo the same phonological processes in Kusaal. Singular and plural nouns that are found in a semantic network are numbered as a single class. It will be demonstrated that nominal classification reveals the perception of the Kusasis on the concept of creation, protection, shapes, basic necessities of life, among other things. In an arbitrary hierarchical representation, the human class is placed supreme to all other classes. Class 1 includes members that have an advantage over all creations; it represents the class of human beings.

Following Breedveld (1995), the associations responsible for grouping nouns in a class are represented in a semantic network. A semantic network connects semantic fields (groups of nouns that share similar semantic features). A circle stands for a semantic field. The common feature that is shared within a semantic field and the association that links this field with other nouns in the same class are written in italics. Examples of members within a semantic field are also written in bold letters. Associative connections (indicating the linking of two items in the same domain of experience) are represented by straight lines. These associative connections can link two semantic fields, two individual nouns, or a semantic field with an individual noun (Breedveld 1995). Below is a discussion on the various classes of nouns in Kusaal.

\section{Class 1: Human-beings and Kin Relationship}

This category is composed of nouns relating to human-beings: nídá/nídíbá 'human being'/'human beings', pú 'áá/ pú 'ábá 'woman'/‘women' and dáu/dápì 'man’/'men'. More predominantly, the class has nouns for kinship terms: pitv/pitiba 'sibling'/'siblings', màà/mànàmà 'mother'/'mothers', pugiba/pugibnama and 'aunt'/'aunts' yáábá/ yáábámà 'grandparent' /'grandparent' /'ancestor'/ 'ancestors'. Other nouns that are observed in this class include: the word for friend(s): zúàal zúàmà 'friend'/'friends', and the word for chief(s): ná 'ábá/ná 'ánàmá 'chief'/‘chiefs'. Agentive nouns that are derived from some deverbal nouns also fall within this category by default. These nouns take the suffixes $-V$ for the singular and $-b a$ for the plural. Examples are núúdi/núúdibá 'drinker' I 'drinkers' and kpáádi/kpáádibá 'farmer'/‘farmers' 
Fig. 1: Semantic Network: Human-beings and Kin Relationship

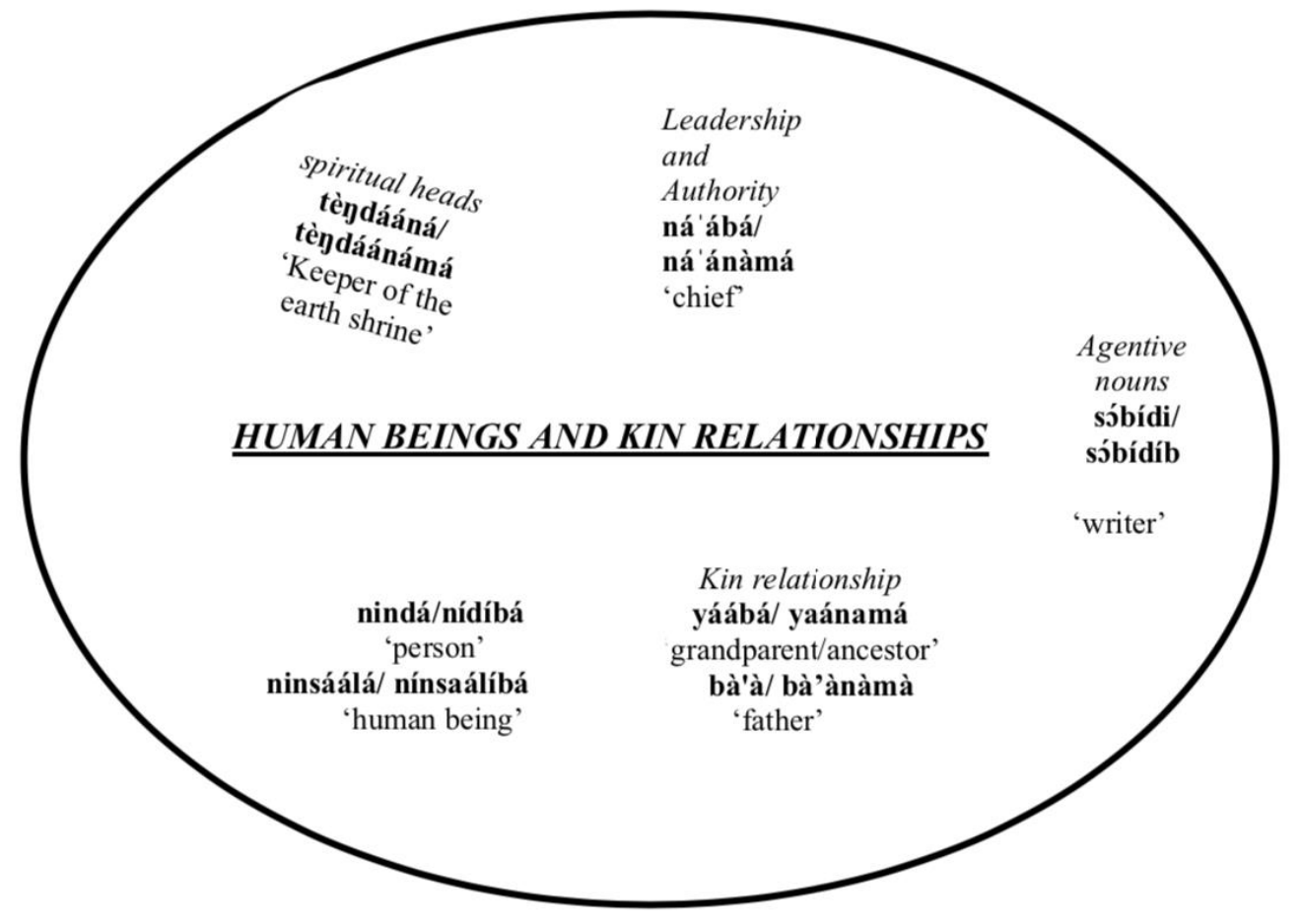

Table 11. Class 1

\begin{tabular}{|c|c|c|c|c|c|}
\hline Class 1 & \multicolumn{2}{|l|}{ Singular } & \multicolumn{2}{|l|}{ Plural } & Gloss \\
\hline \multirow{12}{*}{$\begin{array}{l}\text { Human- } \\
\text { beings and } \\
\text { Kin } \\
\text { Relationships }\end{array}$} & L.E ${ }^{2}$. & D.F. & L. E. & D.F. & \\
\hline & pú'áá & púáá & pú'ábá & pú'áb & 'woman' \\
\hline & nídá & Nid & nídíbá & nídíb & 'person' \\
\hline & sídá & Sid & sídíbá & sídib & 'husband' \\
\hline & pitv & Pit & pitiba & pitíb & 'sibling' \\
\hline & Nínsáálá & ninsáála & nínsaálíbá & nínsáálíb & 'human being' \\
\hline & Màà & $M \grave{a}$ & mànàmà & mànàma & 'mother' \\
\hline & Zúàa & Zúà & zúànàmà & zúà nàm & 'friend' \\
\hline & $b \grave{a}^{\prime} \grave{a}$ & $b \grave{a}^{\prime}$ & bà'ànàmà & bà'ànàm & 'father' \\
\hline & yáábá & yááb & yaánamá & yaánám & 'ancestor' \\
\hline & áansibà & Ánsib & ánsnámá & ansnám & 'uncle' \\
\hline & Púgíbà & Púgíb & púgíbnámá & púgíbnám & 'aunt' \\
\hline \multirow{3}{*}{$\begin{array}{l}\text { Leadership } \\
\text { and } \\
\text { Austhoritv_... }\end{array}$} & ná 'ábá & $n a \grave{a} ' \grave{b} b$ & ná 'ánàmá & ná ánám & 'chief' \\
\hline & Yídááná & yídáán & yídáánáma & yídáánám & 'male \\
\hline & Tèydááná & tèydáán & tèndáánámá & tèndáánám & 'keeper of the \\
\hline
\end{tabular}

${ }^{2}$ L.E (Lexical Entry/Long Form), D.F. (Derived/ Short Form). It is assumed that the short forms are derived from the long counterparts by dropping the final vowels (Abubakari 2017; 2018). 


\begin{tabular}{|l|l|l|l|l|l|}
\hline Spiritual & bá'ábv'gv'di & bá'ábv'gv'd & bá'ábv'gv'díbá & bá'ábv'gv'díb & 'diviner' \\
\hline \multirow{4}{*}{$\begin{array}{l}\text { Agentive } \\
\text { nouns }\end{array}$} & Núúdi & Núúd & núúdíbáa & Núúdib & 'drinker' \\
\cline { 2 - 6 } & kv́v́di & kv́v́d & kv́v́díbá & kv́v́dib & 'killer' \\
\cline { 2 - 6 } & kpaadi & Kpaad & kpaadiba & kpaadib & 'farmer' \\
\cline { 2 - 5 } & sóbídi & sóbíd & sóbídibá & sóbídíb & 'writer' \\
\hline
\end{tabular}

\section{Class 2: 'Non-human' Living Things}

Class 2 is assumed to be the class immediately subordinate to the human class (class 1). This category is referred to as 'Non-human' living things where 'non-human' is metaphorically used to represent the socio-cultural perception that some human-beings are not "fully human". Historically, children born with any form of disability were regarded as "evil spirits" who come to torment their families. The soothsayer is brought in to perform rituals which end up killing these vulnerable persons. This perception, though hardly prevalent these days, is reflected in the semantic classification of nominals such that vulnerable people such as children and the disabled are classified together with trees and animals. The nouns in this class include immature human beings, e.g., biígi/ biísi 'child'/“children', the physically challenged, e.g., wábigá/wábísć 'lame person/'lame persons' and gika/gigisć 'blind person'/'blind person(s)', animals, e.g., bv́v́gl/bv́v́sé 'goat'/'goats', and trees, e.g., kpvkpáríga/kpvkpàrìse 'palm tree'/'palm trees'. Criminals, e.g, na 'ayiigl/na 'ayiise 'thief'/ 'thieves', are also considered to be non-human and belong to this category. This class also has artifacts that are connected by pragmatic associations. Animals and trees, which are "non-human living things", are used for leather and wood respectively. Thus, artifacts like kólv́go/kólíse 'bag'/ 'bags' and wiigi/wiíse 'flute'/'flutes' are connected to this group by virtue of being produced from leather and wood respectively. 
Fig. 2: Semantic Network: 'Non-human' Living Things'

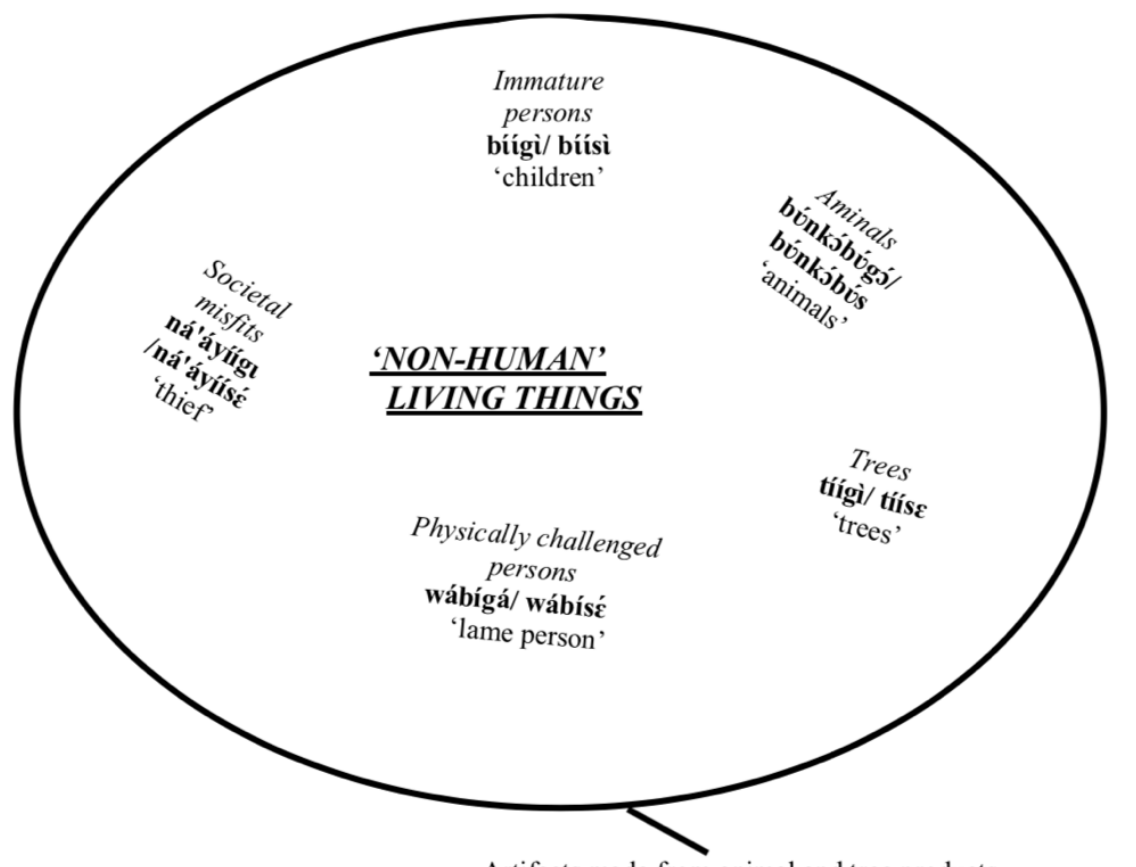

Artifacts made from animal and tree products

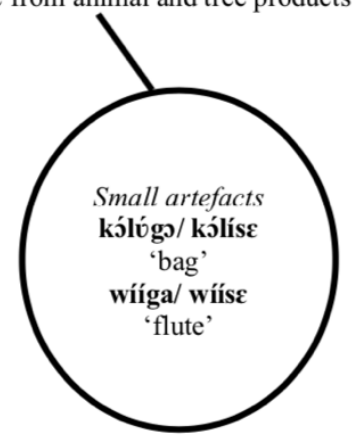

Table 12. Class 2

\begin{tabular}{|c|c|c|c|c|c|}
\hline $\begin{array}{l}\text { Class } 2 \\
-\mathrm{g}(\mathrm{V}) / \mathrm{s}(\mathrm{V})\end{array}$ & \multicolumn{2}{|l|}{ Singular } & \multicolumn{2}{|l|}{ Plural } & \multirow[t]{2}{*}{ Gloss } \\
\hline ‘Non-human’ Living Things & L.E. & D.F. & L. E. & D.F. & \\
\hline \multirow{5}{*}{$\begin{array}{l}\text { children and the physically } \\
\text { challenged persons }\end{array}$} & bíigìá & biíg & biísilé & biís & "child \\
\hline & wábigá & wábíga & wábisć & wábís & 'lame person' \\
\hline & gika & gik & gígísé & gígis & 'dumb person' \\
\hline & zvnzэๆa & $z v n z \supset \eta$ & zonzoose & zonzoos & 'blind person' \\
\hline & ná'áyíígl & ná'áyíígl & nááayíisć & ná'áyíís & 'thief' \\
\hline \multirow[t]{4}{*}{ Animals and trees } & búnkóbúgó & bónkóbóg & búnkj́búsć & bónkj́bús & 'animals' \\
\hline & búv́gl & bóvig & búv́sć & bóv́s & 'goat' \\
\hline & pé'ogìî̀ & pé'òg & pé 'ésé & pé'és & ‘sheep' \\
\hline & lólógó & lólvog & lólísé & lólís & 'ox' \\
\hline
\end{tabular}




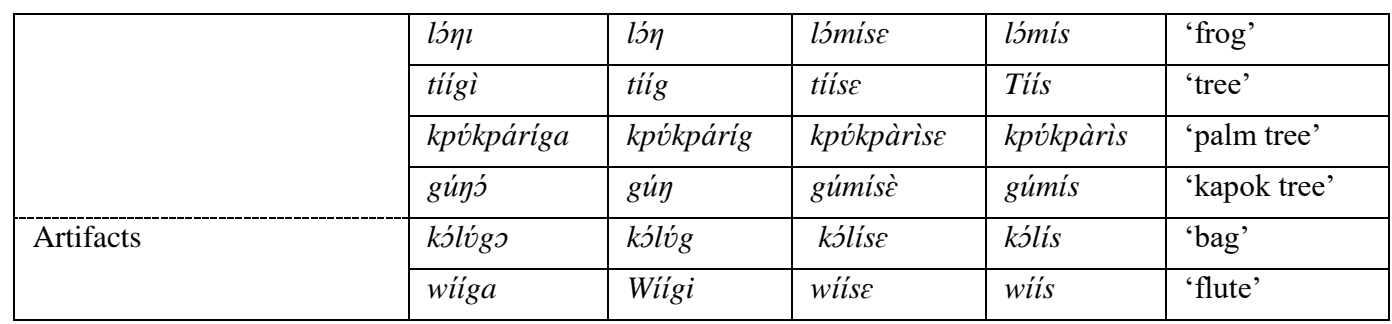

\section{Class 3: Protection}

An integral part of the culture, belief and practices of the Kusasis is the concept of protection. The significance of protection, be it physical, spiritual, mental or psychological, is fundamental on daily basis to the extent that the spiritualist or soothsayer is contacted on all matters before decisions are made. Class 3 comprises nouns that are semantically related to the concept of protection. These forms of protection include protection against the weather, and against war. For instance, shelter and clothes are protective items against the weather. Human beings find shelter in the comfort of places like d'́sgv/ d'́sd 'room'/'rooms' and bón'ógó/bón'ód 'valley'/“valleys', which also mean 'forest'/'forests'. In addition to providing shelter for a wide range of animals, the forest also provides materials that are used for constructing houses. These are dáu'go/dàad 'wood'/“woods' and móǵgo/móód 'thatch'/“thatches'. Notice that mó'́go/móód refers to both 'grass'/"grasses, and 'thatch' /'thatches' just like bón 'ógó/bón ’ód refers to both 'valley'/“valleys', and 'forest'/‘forests'. Items used for protection during war include gbanti 'edvgv/gbanti 'ede 'shield'/'shields' and lókv/lú 'àde 'quiver'/“quivers'. Bón 'ógó/bón'ód 'valley'/“valleys' is a source of spiritual protection; worship and many other sacrifices are often carried out at such places. Fúúgv'fuude refers to all types of garments that are used for covering the body, e.g., 'shirt'/'shirts', and 'cloth'/'clothes'. They provide protection, typically, against the weather. Taa'ara/ta'ada 'shoe'/'shoes' or 'sandal'/'sandals' and zupibid 'hat' (composed of $z u$ - head and -pibid 'cover') do not show any morphological association with this group. Perhaps, historically, shoes and sandals, were not basic requirements in the dressing code of the people and, therefore, not considered as basic protective materials against the weather. The only body-part found in this class is zúgv' zúté 'head/heads'. In the Kusaal tradition and culture, the head is metaphorically used as a symbol of protection, leadership and ownership. God is often referred to as Zugsob 'head.possessor, owner of the heavens, protector of the universe'. The overlord of the Kusaug ${ }^{3}$ Kingdom in Bawku is referred to by title as Zugran 'head.owner', and he is responsible for all issues relating to the welfare of the people. The head is therefore seen as a primary symbol of protection and it is, therefore, no surprise to find it as the only body-part in this category.

\footnotetext{
${ }^{3}$ Kusaug refers to the Kusaal traditional area.
} 
Fig 3. Semantic Network: Protection

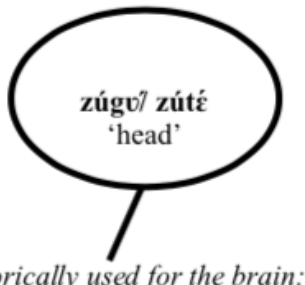

(the head metaphorically used for the brain:

decision making/leadership/spirituality)

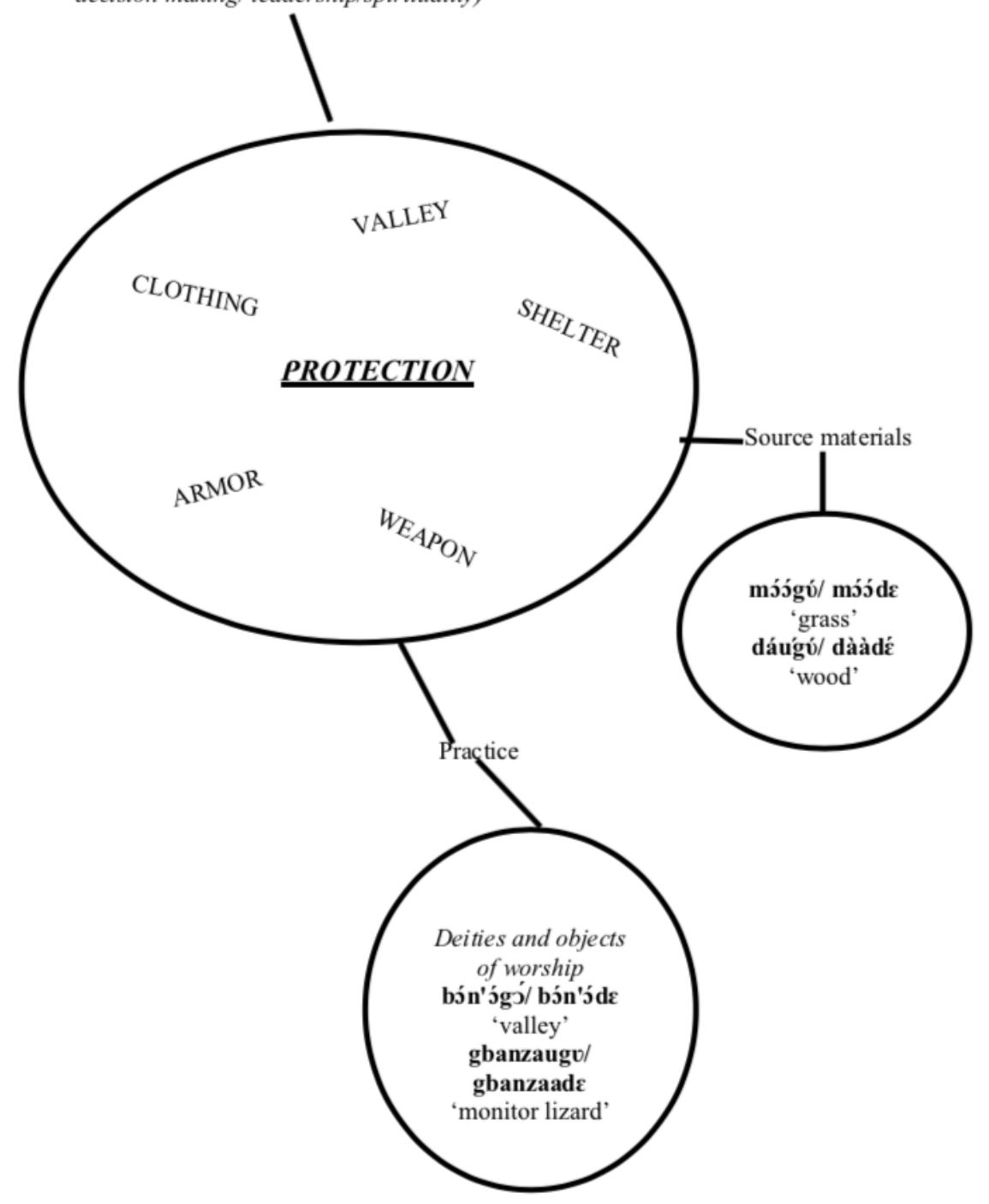


Table 13. Class 3

\begin{tabular}{|c|c|c|c|c|c|}
\hline \multirow{2}{*}{\begin{tabular}{|l} 
Class 3 \\
$-\mathrm{g}(\mathrm{V}) /-\mathrm{d}(\varepsilon)$ \\
Protection
\end{tabular}} & \multicolumn{2}{|l|}{ Singular } & \multicolumn{2}{|l|}{ Plural } & \multirow[t]{2}{*}{ Gloss } \\
\hline & L. E. & D.F. & L. E. & D.F. & \\
\hline & bón'ógó & bón’óg & bón’’́de & bón'sd & 'valley' \\
\hline & dóśgú/s & dójg & dó’de & $d \supset \partial d$ & 'room' \\
\hline & móว́gú/s & móว́g & móóde & mósd & 'grass' \\
\hline & dáugú/s & dàu'g & dààdé & dàad & 'wood' \\
\hline & fúúgv"\%' & fúug & fúúdé & fúúd & 'dress' 'smock' \\
\hline & zúgv'\%' & $z u^{\prime} g$ & 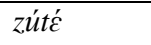 & zút & 'head' \\
\hline & gbanzaugv/s & gbanzaug & gbanzaade & gbanzaad & 'monitor lizard' \\
\hline & lókv/s & lók & lú 'àdé & lú'àd & 'quiver' \\
\hline & gbanti 'edvgv/ o & gbanti'edvg & gbanti 'ede & gbanti'ed & 'shield' \\
\hline
\end{tabular}

\section{Class 4 Totems}

Totems form part of the culture of the Kusasis. The Kusasis are grouped into various clans and each of these clans has a totem. There are about 34 clans in all. Two or more clans may share a common totemic animal. The totemic objects are commonly animals ranging from mammals, reptiles, birds and fishes. These animals are revered by the clans and in terms of disputes or misunderstanding, an oath can be sworn using these animals. It is believed that a culprit may suffer serious repercussions should he or she lie and yet use his/her totemic object/animal to take an oath. Most of these totemic animals occur in various classes; for instance, the frog is a totemic amphibian of the Kpalvg clan and it is found in class 2 and the monitor lizard, a totemic reptile, also for the Kpalvg clan, is found in class 3. The animals that do not occur in other classes also present a common morphological and morphosemantic pattern which constitutes a class. These animals belong to class 4 , which is a very short list. For instance, the horse is the totemic object of the Nabidib clan, the cow and its tail are the totemic objects of the Na'aram clan, and the python is used by the Tensv $\eta$ clan. Whilst it is a taboo for some clans to eat the meat of their totemic animals, other clans are forbidden from eating just some parts of the said animal. People from the Nabidib clan, for instance, cannot eat the tail of the cow which forms part of their totem. 
Fig.4. Semantic Network: Totemic Animals

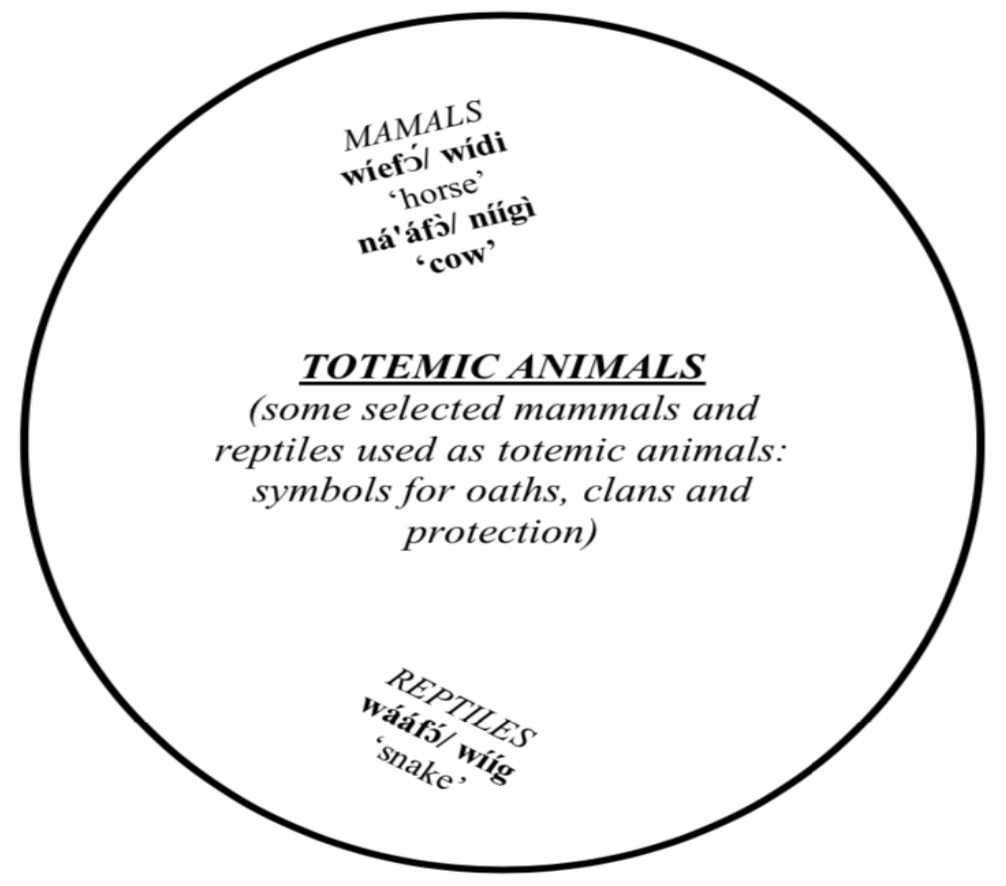

Table 14. Class 4

\begin{tabular}{|c|c|c|c|c|c|}
\hline Class 4 & \multicolumn{2}{|c|}{ Singular } & \multicolumn{2}{|l|}{ Plural } & \multirow[t]{2}{*}{ Gloss } \\
\hline \multirow[t]{5}{*}{ +Totemic Animals } & L. E. & D.F. & L. E. & D.F. & \\
\hline & ná'áfj̀ & ná'áf & niígì & nNiíg & 'cow' \\
\hline & wááf'́ & wááfo & wígì & wiíg & 'snake' \\
\hline & wiefj' & Wiéf & wídì & wid & 'horse' \\
\hline & molufó & Moluf & molisi & molis & 'antelope' \\
\hline
\end{tabular}

\section{Class 5: Shapes}

This group portrays a classification of nominals based on the concept of shape. The nouns in this class reflect a perception associated with shapes. Most of the objects in the group are partly observed, and partly perceived to be round. Until recently, local and traditional houses in Kusaal speaking communities were all round with thatched roofs. This could suggest that the Kusasis, perhaps, prefer the shape "round" to other shapes. It, therefore, comes as no surprise to see the classification of nominals around shape having some association with the shape round. Items that are straight, round, pointed, curved, kite-like, are included. For instance, houses are perceived as round, hence yiri/yaa 'hut', 'house'/'huts', 'houses'. Spherical objects are also perceived as round, e.g., gúv́ré/gúyaa 'cola nut'/‘cola nuts', súmíré/súmá 'groundnut'/ 'groundnuts', etc.. The ear, form its two-dimensional angle, is also perceived as round, hence tvbiri/túbàa 'ear'/‘ears'. Other body parts perceived as round are bin'ísírí/bin'ísaa 'breast'/'breasts' and nyò'v̀ri/nyv̀dàà 'navel'/'navels'. The porcupine séćmé/sécmáa belongs to this group; this is attributed to the fact that it curls itself into 
a round shape when it is touched. Some items that are not obviously related to shape but to dimension are also included. These are nyúúré/nyúyáá 'yam'/‘yams' and źv́rre/ zv́yaa 'tail'/‘tails'. One may argue that yam slices are often cut in round hence its inclusion in this group. What remains a puzzle is the inclusion of 'tail', and more so the inclusion of gbigimé/gbigimáa 'lion'/'lions' in this category.

Fig. 5 Semantic Network: Shapes

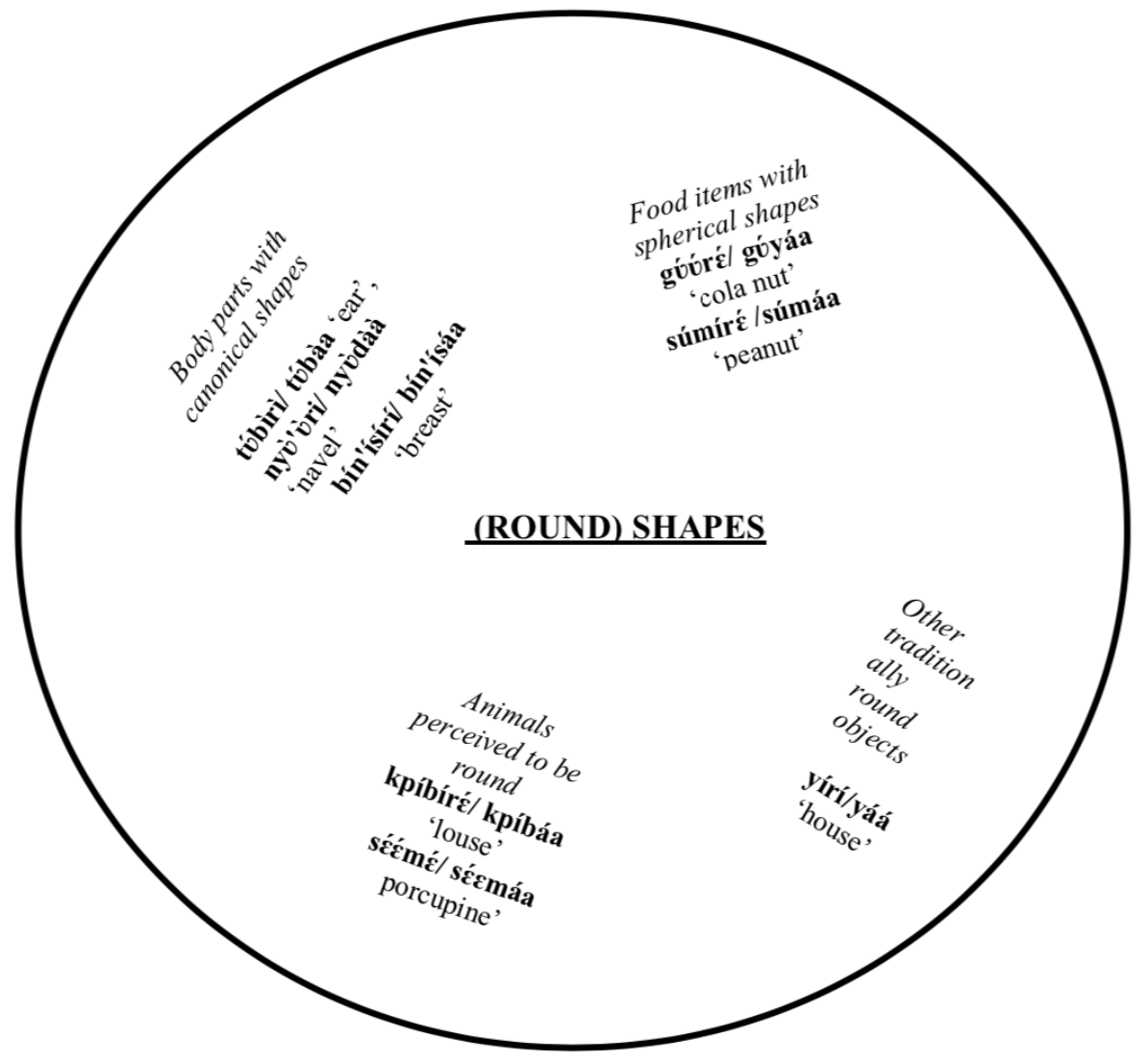

Table 15. Class 5

\begin{tabular}{|c|c|c|c|c|c|}
\hline Class 5 & Singular & & Plural & & Gloss \\
\hline Shapes (Round) & L. E. & D.F. & L. E. & D.F. & \\
\hline & tóbìrì/ع & tóbìr & tóbàa & tóba & 'ear' \\
\hline & nyò'òri & nyò'v̀r & nyòdàà & nyòdà & 'navel' \\
\hline & bín'ísírí/ع & bín'ísír & bín'ísáa & bín'ísá & 'breast' \\
\hline & zóúre & zóór & zóyaá & zóya & 'tail' \\
\hline & wílle & wíl & wíláa & wíla & 'stem' \\
\hline & yírí & yír & yáá & yá & 'house' \\
\hline & nyúúú́ & nyúúre & nyúyáa & nyúyá & 'yam' \\
\hline & gưoúré & gúoúr & gúyáa & gúyá & 'cola nut' \\
\hline
\end{tabular}




\begin{tabular}{|c|c|c|c|c|c|}
\hline & béyìr & bénìr & béyáa & béya & 'bean' \\
\hline & súmíré/1 & súmír & súmáa & súmá & 'groundnut' \\
\hline & kpíbíré/l & kpíbìr & kpíbáa & kpíbá & 'louse' \\
\hline & sććmé & sććm & sćcmáa & sććmá & 'porcupine' \\
\hline & gbígímé/ı & gbígìm & gbígìmáa & gbígìmá & 'lion' \\
\hline
\end{tabular}

\section{Class 6: Non-count Nouns}

This is the class for non-count nouns. Abstract entities are included here because they cannot be counted as well. They include basic necessities of life for the survival of the people.

Fig. 6. Non-count Nouns

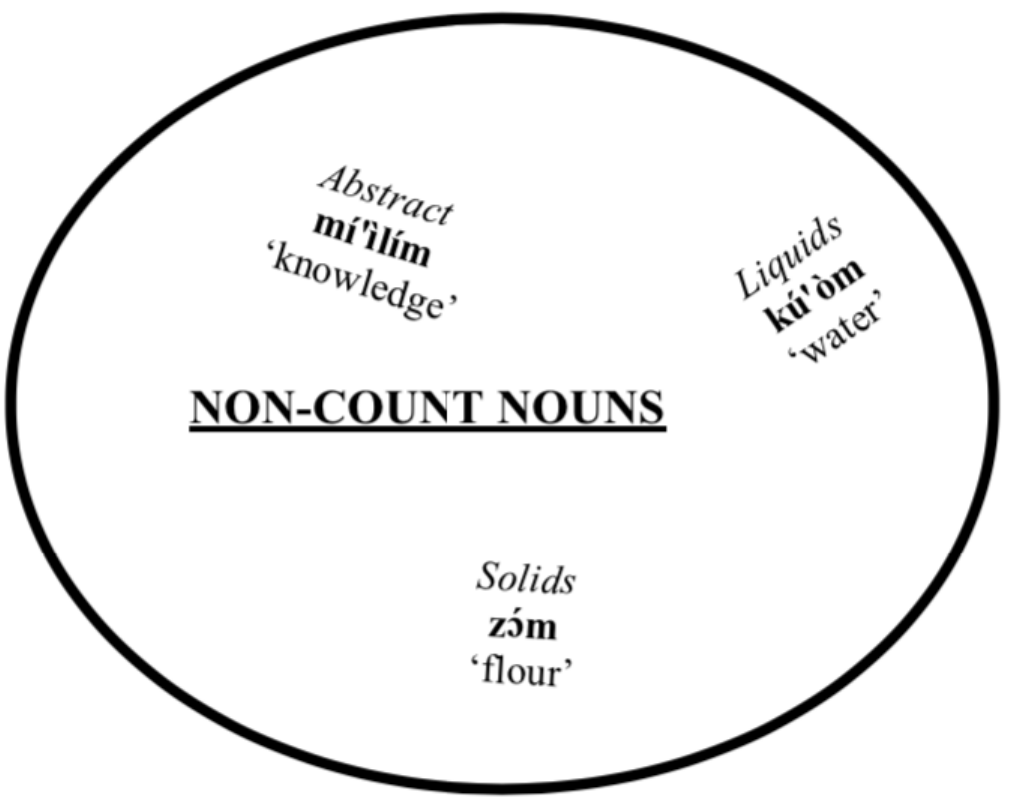

Table 16 Class 6

\begin{tabular}{|l|l|l|}
\hline $\begin{array}{l}\text { Class 6 } \\
-\mathrm{m}\end{array}$ & Mass nouns & Gloss \\
\hline \multirow{4}{*}{ Noun-count Nouns } & kú'òm & 'water' \\
\cline { 2 - 3 } & ziím & 'blood' \\
\cline { 2 - 3 } & bín'ísím & 'milk' \\
\cline { 2 - 3 } & kpáám & 'oil' \\
\cline { 2 - 3 } & dìndó'vóróm /dòndó'v́ncm & 'urine' \\
\cline { 2 - 3 } & mi'ìlím & 'knowledge' \\
\hline
\end{tabular}




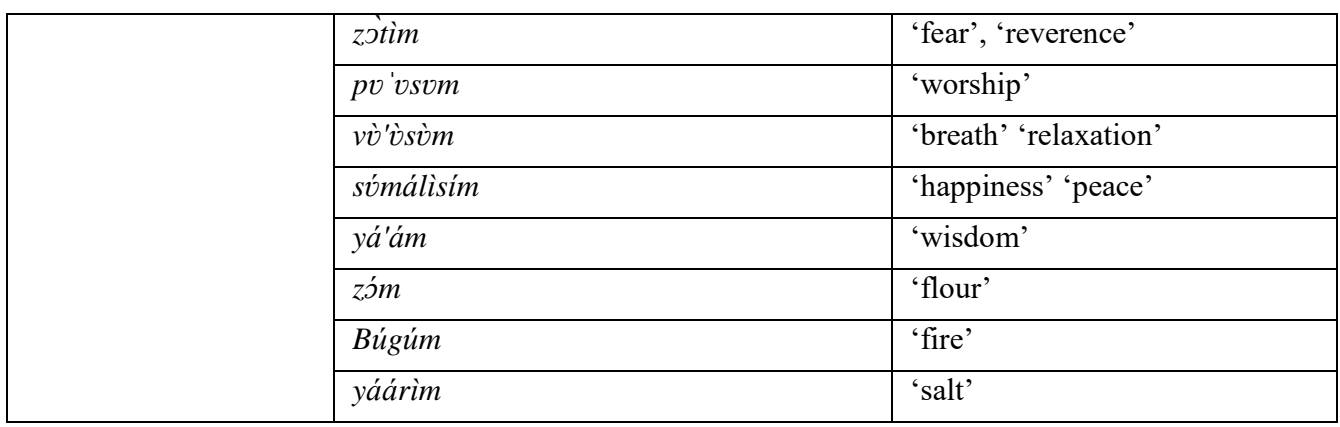

This section has demonstrated the morphosemantic correspondences between nouns in the various classes. It is observed that nouns that share identical semantic qualities also show identical morphological features by taking the same suffix morphemes.

\section{Conclusion}

The table in 18 illustrates the morphosemantic correspondences between nouns in the various classes as well as the common phonological processes that these nouns are subjected to. Nouns that belong to a common semantic network also show identical morphological features, by taking the same suffix morphemes, and similar phonological rules or constraints. Generally, the table shows the relationship between morphology, semantics and phonology in the nominal classification of Kusaal where nouns in identical groups form a semantic network of association.

Table 18. Morphosemantics and the morphological contents of noun classes in Kusaal

\begin{tabular}{|c|c|c|}
\hline Semantic Classifications & Suffix Morphemes & Phonological Processes \\
\hline $\begin{array}{l}\text { Class } 1 \\
\text { Human-beings and Kin Relationships }\end{array}$ & $\begin{array}{l}\text { /-a/, /-b(V)/, } \\
/-\operatorname{nam}(a) /\end{array}$ & $\begin{array}{l}\text { Vowel Insertion, } \\
\text { Final Vowel Deletion }\end{array}$ \\
\hline $\begin{array}{l}\text { Class } 2 \\
\text { 'Non-human' living things }\end{array}$ & $\begin{array}{l}/-g(\mathrm{~V}) / \\
/-s(i / \varepsilon) / \\
/-m i s(i / \varepsilon) /\end{array}$ & $\begin{array}{l}\text { Vowel Lengthening, } \\
\text { Final Vowel Deletion }\end{array}$ \\
\hline $\begin{array}{l}\text { Class } 3 \\
\text { Protection }\end{array}$ & $/-g(\mathrm{~V}) /, /-d(\varepsilon) /$ & $\begin{array}{l}\text { Vowel Lengthening, } \\
\text { Final Vowel Deletion }\end{array}$ \\
\hline $\begin{array}{l}\text { Class } 4 \\
\text { Totemic Animals }\end{array}$ & $\begin{array}{l}/-f(\mathrm{~V}) /, \mid-g i / \\
/-d i /\end{array}$ & $\begin{array}{l}\text { Vowel Assimilation (regressive), } \\
\text { Final Vowel Deletion }\end{array}$ \\
\hline $\begin{array}{l}\text { Class } 5 \\
\text { Shapes } \\
\end{array}$ & $/-r(\mathrm{~V}) /, /-a(a) /$ & $\begin{array}{l}\text { Consonant Insertion/Vowel } \\
\text { Insertion, Final Vowel Deletion }\end{array}$ \\
\hline $\begin{array}{l}\text { Class } 6 \\
\text { Non-count Nouns }\end{array}$ & $/-\mathrm{m} /$ & - \\
\hline
\end{tabular}

Although this paper focuses on Kusaal, the findings may as well have a bearing on the nominal classification of other Mabia (Gur) languages where identical semantic and morphological patterns are observed for the various established noun classes. 


\section{List of abbreviations}

$\begin{array}{ll}\text { DEF } & \text { Definite Article } \\ \text { Sg. } & \text { Singular } \\ \text { Pl } & \text { Plural } \\ \text { Poss } & \text { Possessive } \\ \text { Q } & \text { Question Element } \\ \text { NEG } & \text { Negative } \\ \text { L. E. } & \text { Lexical Entry } \\ \text { D.F. } & \text { Derived Form } \\ \text { Adj. } & \text { Adjective } \\ \text { Sfx } & \text { Suffix } \\ \text { WFR } & \text { Word Formation Rule } \\ \text { VH } & \text { Vowel Harmony } \\ \text { VL } & \text { Vowel Lengthening } \\ \text { VI } & \text { Vowel Insertion } \\ \text { CI } & \text { Consonant Insertion } \\ \text { FVD } & \text { Final Vowel Deletion }\end{array}$

\section{References}

Abubakari, Hasiyatu. 2011. Object-sharing as symmetric sharing: Predicate clefting and serial verb constructions in Kusaal. Master Thesis, University of Troms $\emptyset$.

Abubakari, Hasiyatu. 2017. Ideophones in Kusaal. Journal of West African Languages, Vol. 44.1: 42-57.

Abubakari, Hasiyatu. 2018. Aspects of Kusaal Grammar: The Syntax-Information Structure Interface. PhD. Dissertation, African Studies Department: University of Vienna.

Abubakari, Hasiyatu. 2020. Personal Names in Kusaal: A Sociolinguistic Analysis. Language \&Communication, Vol 75:21-35.

Agyekum, Kofi. 2006. The Sociolinguistics of Akan Personal Names. Nordic Journal of African Studies 15(2): 206-235

Anttila, A. and Bodomo, Adams. 2009. Prosodic morphology in Dagaare. In Fiona McLaughlin, Eric Potsdam, and Masangu Matondo (eds.), Select Proceedings of the 38th Annual Conference on African Linguistics, pp.56-68. Somerville, Massaschusetts: Cascadilla Proceedings Project.

Bodomo, Adams. 2020. Mabia: its etymological genesis, geographical spread, and some salient genetic features. In Adams, Bodomo, Hasiyatu Abubakari and Samuel, Alhassan Issah (eds.), Handbook of the Mabia Languages of West Africa, pp. 5-34. Glienicke: Galda Verlag.

Bodomo, Adams. and Abubakari, Hasiyatu. 2017. Towards the harmonisation of a writing technology for the Mabia Languages of West Africa. In Kwesi Kwaa Prah \& Lazarus Musazitame Miti (eds.), Deconstructing the African Tower of Babel:Between the Harmonisation and Fragmentation of African Language Orthographies. CASAS Book Series No. 120:159-181. Cape Town: Centre for Advanced Studies of African Society.

Bodomo, B. Adams. 1997. The Structure of Dagaare. Stanford: Stanford Monographs in African Languages, CSLI publications. 
Bodomo, B. Adams. \& Marfo, O. Charles. 2006. The Morphophonology of noun classes in Dagaare and Akan. Studi Linguistici e Filologici Online 4.2(205-243). Dipartimento di Linguistica Università di Pisa. www.humnet.unipi.it/slifo

Bodomo, Adams. 1993. Complex predicates and event structure: An integrated analysis of serial verb constructions in the Mabia languages of West Africa. Working papers in Linguistics. 20. Department of Linguistics, University of Trondheim, Norway.

Breedveld, Anneke, 1995. The semantic basis of noun class systems: the case of the KI and NGE classes in Fulfulde. Journal of West African Studies; XXV.2:63-75

Contini-Morava, Ellen. 1994. Noun Classification in Swahili: A cognitive-semantic analysis using a computer database. In Robert K. Herbert (ed.), African Linguistics at the Crossroads. Papers from Kwaluseni, 1st World Congress of African Linguistics, Swaziland, 18-22. VII. 599-628. Köln: Rüdiger Köppe.

Dakubu, M. Easther. 1996. Grammar of Gurene. Trial Edition. Legon: Language Centre.

Eddyshaw, David. 2019. A grammar of Kusaal: Agolle Dialect. Available online at https://www.academia.edu/30678520/A_grammar_of_Kusaal

Heine, Bernd. 1982. African noun class systems. In H. Seiler and C. Lehmann (eds.) Apprehension: das sprachliche Erfassen von Gegenständen.Vol.1(189-216). Tübingen: Gunter Narr Verlag.

Katamba, Francis. 2003. Bantu nominal morphology. In Derek Nurse and Gérard Philippson (eds.), The Bantu Languages, pp103-120. New York: Routledge.

Kiparsky, Paul. 1985. Some Consequences of Lexical Phonology. Phonology Yearbook 2:85-138. Great Britain: Cambridge University Press.

Lakoff, George. 1987. Classifiers as a reflection of the mind. In Colette Craig (ed.), Noun classes and categorization. Typological Studies in Language 7:13-51. Amsterdam: John Benjamins.

Miehe, Gudrun, Brigitte Reineke. \& Kerstin Winkelmann (eds). (2012). Noun Class Systems in Gur Languages. Vol. II North Central Gur Languages (without Gurunsi). Köln: Köppe.

Miehe, Gudrun \& Kerstin Winkelmann (eds.). 2007. Noun Class Systems in Gur Languages. Vol. I Southwestern Gur Languages (without Gurunsi). Köln: Köppe.

Mohanan, K.P. 1986. The Theory of Lexical-Phonology, Dordrecht: Reidel.

Mphande, Lupenga, 2006. Naming and linguistic Africanisms in African American Culture. In: Megane, J. et al. (Eds.), Selected proceedings of 35th Annual Conference on African Linguistics, 104-113. Somerville, MA: Cascadilla Proceedings Project.

Musah, A. Agoswin. 2018. A grammar of Kusaal: A Mabia (Gur) language of northern Ghana. Berlin: Peter Lang.

Naden, Tony. 1989. Gur. In: Bendor-Samuel, John (ed.), The Niger-Congo Languages, Lanham New York - London: University Press of America; 140-168.

Niggli, A.Urs. 2014. Grammaire élémentaire du Kusaal. Société International de Linguistics.

Nsoh, N. Avea. 2002. Classifying the nominal in the Gurene dialect of Farefare of Northern Ghana. Journal of Dagaare Studies Vol.2: 83-95.

Olawsky, J. Knut. 1999. Aspects of Dagbane grammar, with special emphasis on Phonology and Morphology. PhD dissertation. Munich: LINCOM Academic Publishers.

Olawsky, J. Knut. 1997. Interaction of tone and morphology in Dagbane. DGfS- Tagung in Düsseldorf. Retrieved on 30/01/2020 from: https://user.phil-fak.uniduesseldorf.de/ olawsky/hp-dgfs.htm

Rapp, Eugen Ludwig. 1966. Die Gurene Sprache in Nord Ghana. Leipzig: VEB Verlag Enzyclopaedie. 
Sapir, Edward. 1949. Language and environment. In: D. Mandelbaum (ed.), Selected writings of Edward Sapir, 89-103. Berkley: University of California Press.

Schuh, Russel. 1995. Avatime noun classes and concord. Studies in African Linguistics, Vol 24:2. Pp 123-149.

Welmers, E. William. 1973. African Language Structures. Berkeley: University of California Press.

Wilson, W.A.A. 1971. "Class Pronoun Desuetude in the Moore-Dagbani Sub-Group of Gur". Journal of West African Languages. Vol.III, No. 2: 79-83.

Hasiyatu Abubakari <abu.hasiyatu@gmail.com>

University of Ghana, Legon 